DOI: $10.30519 /$ ahtr.687956

Advances in Hospitality and Tourism Research (AHTR)

\title{
EXPLORING THE COLLABORATIVE CONSUMPTION JOURNEY: THE CASE OF ACCESS-BASED CONSUMPTION
}

\author{
Özge ÖZGEN 1
}

Department of International Business and Trade, Dokuz Eylul University, Turkey ORCID: 0000-0002-1328-3658

\author{
Nilay BIÇAKCIOĞLU-PEYNIRCİ \\ Department of International Business and Trade, Dokuz Eylul University, Turkey \\ ORCID: 0000-0002-7705-3827
}

\begin{abstract}
This study explores the collaborative consumption journey in purchase funnel, covering both the pre-accommodation and during/post-accommodation stages, and extends knowledge toward the intersection of customer experience and the field of shared economics. Firstly, we identify all potential touchpoints in multiple stages of the collaborative consumption journey through in-depth interviews and then we investigate experiential dimensions of the collaborative consumption journey by means of a qualitative study and the prioritization of dimensions of customer experience through the Analytical Hierarchical Process methodology by analysing two different types of access-based consumption: the renting platform Airbnb and the lending platform Couchsurfing. Touchpoints were framed under four groups: (a) brand-owned, (b) partner-owned, (c) customer-owned and (d) social/external. The results demonstrate that sensory, affective and cognitive dominant experiences act as the primary roles for both collaborative consumption platforms in the pre-accommodation stage, whereas the collaborative consumption experience is enriched with distinct experiences in the during/postaccommodation stage. The cognitive experience is relatively more important for Airbnb, while sensory experience plays
\end{abstract}

\section{Article History}

Received 11 February 2020

Revised 7 September 2020

Accepted 10 September 2020

\section{Keywords}

Customer journey

Touchpoint

Collaborative consumption

Sharing economy

Airbnb

Couchsurfing

\footnotetext{
${ }^{1}$ Address correspondence to Özge ÖZGEN (PhD), Department of International Business and Trade, Faculty of Business, Dokuz Eylul University, Izmir, TURKEY. E-mail: ozge.ozgen@deu.edu.tr
} 
a more critical role in the Couchsurfing journey in the preaccommodation stage. These experiences then shift into affective and relational experiences during/postaccommodation stage.

\section{INTRODUCTION}

Providing superior value to customers in the form of experience creates a competitive advantage in today's business environment, and managers have become progressively more enthusiastic about the experience concept (Berry et al., 2002; Verhoef et al., 2009). The customer experience has become a new competitive battleground. It is a critical antecedent of favourable business outcomes (customer retention and profitability) and a source of sustainable differentiation beyond traditional physical elements such as product features, price, delivery, and lead times (Bolton et al., 2014)

Technological developments are transforming the customer experience, and the nature of interactions between customers and organizations are changing considerably (Van Doorn et al., 2017). Today, customers face and interact with companies through various touchpoints in the digital, physical, and social realms (Bolton et al., 2018), which together make the customer journey more complicated. Scrutinizing these touchpoints during customers' journeys through myriad interactions in the different stages of purchase such as pre-purchase, purchase and postpurchase is critically important for companies that intend to create and deliver augmented customer experiences (Baxendale et al., 2015; Bolton et al., 2014; Verhoef et al., 2009). Moreover, elaborating the journey with its details across every touchpoint creates multiple effects on customers (Bolton et al., 2014). In this sense, since creating a magnificent customer experiences is paramount for companies, most multinational companies now have chief customer experience officers working on managing their customers' experiences in an organized manner (Verhoef et al., 2015).

Customer experience has been studied in several research areas, including online marketing (e.g., Novak et al., 2000), brand management (e.g., Brakus et al., 2009), retail marketing (e.g., Bagdare \& Jain, 2013) and service marketing (e.g., Voorhees et al., 2017), while analyses of the collaborative consumption journey remains unexamined in the literature. In addition, many researchers do not explicitly differentiate the various forms of collaborative consumption platforms (Möhlmann, 2015). The new "sharing economy" phenomenon, which has directly changed the mindsets of consumers over recent decades, has received a 
great deal of attention among entrepreneurs, policy-makers, the media and academic scholars (Lamberton \& Rose, 2012). While traditional economic perspectives advocate the "transfer of ownership" for the exchange of goods and services, the sharing-based economy introduced a new concept, "access over ownership", involving activities such as borrowing, lending and renting instead of purchasing and owning (Botsman \& Rogers, 2010). In this framework, individuals' increased attention toward environmental, societal and economic concerns in recent years has made the "collaborative consumption" model an inevitable alternative for consumers (Botsman \& Rogers, 2010). In addition, access-based consumption may also differ with respect to market mediation, implying that some modes of exchange are triggered by prosocial and altruistic motives (i.e., Couchsurfing), while others can be underlined by economic and reciprocal desires (i.e., Airbnb) (Bardhi \& Eckhardt, 2012); such motives should be expected to alter consumers' preferences and experiences in their collaborative consumption journeys in the future.

On the other hand, despite widespread studies of customer journeys in recent literature, scant attention has been given to the formalization of the methodology through examining the customer journey (Halvorsrud et al., 2016). As the pertinent literature mainly concentrates on the conceptualization of the construct (e.g., Brakus et al., 2009; Verhoef et al., 2009), it is also important to investigate the customer journey itself in various stages of the purchasing process by focusing on multiple touchpoints. The literature also remains silent on the affective, cognitive, emotional, relational and behavioural dimensions of experience (Bolton et al., 2014) that exist in the pre-purchase, purchase and post-purchase stages of the journey (Kranzbühler et al., 2018). Although there exist several studies investigating the subject of sharing in sociology and anthropology, limited attention has been given to the concept in the fields of consumer behaviour and consumption (Hellwig et al., 2015), which is especially promising in customer experience field (Paulauskaite et al., 2017).

Motivated by the abovementioned factors, the overall objective of this study is to explore the collaborative consumption journey in purchase funnel. This study offers a twofold contribution to the existing research through its objective: the first will be to shed light on the collaborative consumption journey in monetary and nonmonetary contexts by associating touchpoints with various dimensions of experiences in different stages of the journey. Secondly, this study is designed to bridge consumers' and practitioners' perspectives on how to enrich the collaborative consumption experience, overcome barriers for it and the painful points of 
the collaborative consumption journey. In doing so, this paper addresses the following questions:

(1) What are the touchpoints in purchase funnel for customer journey at the collaborative consumption platforms Couchsurfing and Airbnb?

(2) What are the experiential aspects in different stages of the collaborative consumption journey for Airbnb and Couchsurfing? What are the weights of those different experiential aspects?

(3) What are the differences in journey between renting (i.e., Airbnb) and lending (i.e., Couchsurfing) as forms of collaborative consumption?

(4) What can scholars and practitioners suggest in order to enrich the collaborative consumption journey in the context of renting (i.e., Airbnb) and lending (i.e., Couchsurfing)?

To answer these questions, this paper proceeds with a literature review comprising both the customer journey and sharing economy. Following an overview of the literature, the collaborative consumption journeys of Airbnb and Couchsurfing customers were investigated using a combination of qualitative and quantitative methods. In Study 1, semistructured interviews were used to identify key brand touchpoints in the pre-purchase, purchase and post-purchase stages for customers. Study 2 explored the experiential dimensions of the collaborative consumption journey through a qualitative study and then prioritized these dimensions of customer experience with the help of an analytical hierarchical process methodology. Finally, a general discussion and managerial implications for collaborative consumption platforms are provided, along with considerations for future research.

\section{THE CUSTOMER JOURNEY}

The concept of the customer experience was first uttered in the 1980s; this new experiential view focused on the symbolic, hedonic and aesthetic nature of consumption, and progressed beyond conventional consumer behaviour literature which had previously examined consumption as a rational decision-making process (Holbrook \& Hirschman, 1982). According to Meyer and Schwager (2007), the customer experience as a holistic concept incorporates all aspects of a company's offerings, such as quality of customer care, product and service features. It also denotes the internal and subjective responses of customers as they come into direct or 
indirect contact with a company. Namely, the customer experience is derived from interactions between a customer and a company, a product, or partners of a company (Gentile et al., 2007). These interactions extend to customer-to-customer interactions, though it is often difficult to distinguish how they affect purchase decisions (Davies et al., 1999). Managing customer experiences is multifaceted for services which are often co-produced by several service providers for multiple customers (Bolton et al., 2014). Contrary to the goods-centred view of marketing, Vargo and Lusch (2004) indicated that customer experience is not designed; rather it is co-created through customer interactions with numerous service elements.

Customer experience in a journey can be examined theoretically through five different dimensions (Schmitt, 1999): (1) sensory experience (sense); (2) cognitive experience (think); (3) affective experience (feel); (4) behavioural experience (act); and (5) social-identity experience (relate). Sensory experience is related to the five human senses (sight, sound, smell, taste and touch) and, though it is often neglected in the marketing literature, arouses aesthetical pleasure, excitement, satisfaction, beauty perception, memory and emotion (Hultén, 2011). In terms of the cognitive dimension, an experience acts as a personal trial which transforms individuals or allows them to develop certain philosophical, sociological and psychological perspectives (Carù \& Cova, 2003). In this framework, cognitive experiences refer to thinking, conscious mental processes and creatively examining mental assumptions held by marketers (Gentile et al., 2007). Brakus et al. (2009) posit that cognitive experiences include convergent/analytical and divergent/imaginative thinking. While convergent thinking is focused on deriving the single best or correct answer, divergent thinking (e.g. creative thinking, shifting perspectives and seeing new possibilities), by contrast, involves producing unconventional answers from existing information (Cropley, 2006). Besides providing cognitive experiences, marketers trigger customers' internal feelings and emotions with the objective of creating worthy affective experiences (Schmitt, 1999). In the literature, previous studies highlight the importance of affective experiences. For instance, Schmitt et al. (2015) suggest that experience is a mediator between consumption and the hedonic path (pleasure), and also the eudamonic path (the fulfilment of meaningful goals) of happiness. Berry et al. (2002) reveal that organizations must take into account the emotional component of experiences with the same rigor as product management and service functionality. The fourth dimension, the behavioural experience, refers to motor actions and acts of doing (Gentile et al., 2007). Finally, the social 
identity experience refers to social experiences, such as relating to a reference group (Brakus et al., 2009)

Consumer and marketing research has shown that experiences constitute key markers in all stages of the customer purchase journey - from need recognition to post-purchase stages (Brakus et al., 2009; Lemon \& Verhoef, 2016). From a holistic perspective, all stages should be taken into consideration in the journey, and as Voorhees et al. (2017) suggest, researchers must expand their views beyond core experiences. In this context, customer experience can be conceptualized as "a customer's journey with a firm over time during the purchase cycle across multiple touchpoints" (Lemon \& Verhoef, 2016, p. 74). According to Homburg et al. (2017), who worked with 52 managers on questions of customer experience management, creating and managing a consistent experiential response across different touchpoints is essential for companies. Touchpoints need not be linked directly to a company or go beyond channels; rather, they may consist of any interaction, such as word-of-mouth or reviews in which the firm is not directly involved (Baxendale et al., 2015). Existing studies propose various classifications of customer touchpoints within the customer journey (e.g., Anderl et al., 2016; Lemon \& Verhoef, 2016). For example, digital channels were categorized as paid channels (e.g. TV, radio), owned channels (e.g. a company's website) and earned channels (e.g. consumer reviews on blogs) (Stephen \& Galak, 2012). Furthermore, Anderl et al. (2016) focused on question of who instigates the interaction, and in so doing, grouped touchpoints as both firm-initiated and customerinitiated. Straker et al. (2015) classified touchpoints under four categories: functional touchpoints (e.g. websites, email), social touchpoints (e.g. Facebook, Instagram), community touchpoints (e.g. discussion forums, blogs) and corporate touchpoints (e.g. FAQs). Finally, Lemon and Verhoef (2016) categorized touchpoints managed by the firm and existing under the firm's control (e.g. advertising, websites) as brand-owned touchpoints. According to their typology, while partner-owned touchpoints are designed and managed by one or more of the company's partners, customer-owned touchpoints exist under the control of customers. Last but not least, social/external touchpoints refer to third-party information sources (e.g. review sites). The increasing number and complexity of potential customer touchpoints, under the effect of accelerated technological development, render the understanding of the customer journey increasingly difficult owing to the reduced control firms have over the customer experience and journey (e.g., Edelman \& Singer, 2015). 


\section{COLLABORATIVE CONSUMPTION}

Sharing is one of the most fundamental patterns of human economic behaviour, and its presence as a form of exchange in humankind has been dated back several thousand years (Price, 1975). Among today's consumers, sharing as a form of consumption has recently become, in some respects, more attractive than buying, particularly in the course of heightened interest in public and academic bodies for more sustainable models of consumption (Belk, 2014; Hellwig et al., 2015; Lamberton \& Rose, 2012). A wealth of conceptions of the sharing economy exist in the pertinent literature (Richardson, 2015), and there appears to be different terms employed interchangeably with "sharing economy" (Dredge \& Gyimóthy, 2015), including "peer-to-peer economy" (Nielsen, 2014), "collaborative consumption" (Botsman \& Rogers, 2010), "social sharing" (Benkler, 2004) and "access economy" (Rifkin, 2000).

According to Belk (2014, p. 1597), however, sharing can be defined as "people coordinating the acquisition and distribution of a source for a fee or other compensation", referring to the involvement of both monetary and non-monetary compensations. On the other hand, Hamari et al. (2016) describes sharing as the consumption of goods and services through activities such as renting, swapping, or trading; their definition points to different modes of sharing, such as new and second-hand purchases, donating, lending, renting and borrowing. The concept may also refer to "systems of organized sharing, bartering, lending, trading, renting, gifting, and swapping" (Botsman \& Rogers, 2010, p. 30). Further, access of ownership refers to the sharing of goods and services with other individuals for a limited time period through peer-to-peer sharing activities such as renting and lending (Bardhi \& Eckhardt, 2012). In line with these definitions, commercial sharing business models allow individuals to share their own resources with other people in new and creative platforms (Cohen \& Kietzmann 2014). For instance, people are empowered to provide access to flats (e.g., AirBnB, Couchsurfing), cars and bicycles (e.g., Sidecar, Byke.mobi), clothes (e.g., Poshmark) and taxi services (e.g., Uber, blablacar) (Malhotra \& Van Alstyne, 2014). However, access-based consumption platforms are different from each other depending on the level of market mediation, from for-profit to not-for-profit. For instance, while not-forprofit access-based consumption platforms rely heavily on peer-to-peer sharing and consumers gain temporary access to goods/services owned by other people for free (i.e., Couchsurfing), some access-based consumption platforms are contingent on market mediation, stimulated by the profitmotives of economic exchange (i.e., Airbnb) (Bardhi \& Eckhardt, 2012). In 
this sense, consumers' perceptions, values and desires differ with regard to the mode of consumption, and consumers may have different preferences for distinct types of access-based consumption (Chen, 2012; Rifkin, 2000).

The aspects of the sharing economy are fourfold: (1) collaboration online, which covers issues such as content creation by sharing knowledge or collaborative facilities among users online- such as consumer to consumer exchanges like file sharing (Kaplan \& Haenlein, 2010); (2) social commerce, which refers to peer-to-peer cooperation as a form of commerce through social media (Wang \& Zhang, 2012); (3) sharing online, which refers to the sharing of goods and services with the help of information technologies such as collaborative consumption platforms like Couchsurfing and Blablacar (Galbreth et al., 2012); and finally, (4) ideological considerations, which are attached to collective actions or campaigns via open sources such as social media (Oh et al., 2013).

Since it allows for the sharing of goods and services in exchange for monetary and nonmonetary benefits and reconceptualises the notions of "ownership" and "employment" (Belk, 2014), "sharing rather than purchasing" has gained increased popularity among today's consumers owing to its three main premises for the economy (i.e., generating new revenue models for individuals), society (i.e., increased social interactions) and the environment (i.e., communal consumption) (Hellwig et al., 2015; Madran \& Yakın, 2018). With regard to its economic impacts, PwC has estimated that the five main industries in the context of sharing-based economies (i.e., travel, car sharing, staffing, music and video streaming) generate $\$ 15$ billion in global annual revenue today, and forecasters suggest a market potential of up to $\$ 335$ billion by 2025 (PwC, 2016). On the other hand, both companies and individuals have begun to consider the option of sharing as an environmentally-friendly and more profitable alternative to purchasing goods and services (Botsman \& Rogers, 2010). In this context, the sharing economy is considered an umbrella concept incorporating the concept of "collaborative consumption", which encourages the sharing and consumption of goods and services via online platforms (Hamari et al., 2016).

\section{METHODOLOGY}

In this research, the process of exploring the collaborative consumption journey consisted of two studies. In Study 1, in-depth interviews were conducted with the aim of identifying and classifying all potential 
touchpoints in multiple stages of the collaborative consumption journey. Study 2 is designed with the intent to: (1) explore the sensory, affective, cognitive, behavioural and relational experience dimensions of the collaborative consumption journey; (2) prioritize dimensions of the customer experience for two different collaborative consumption platforms (Airbnb and Couchsurfing); and (3) determine critical touchpoints for customers in the collaborative consumption journey by focusing on the pre/during/post accommodation stages of the journey.

\section{Selection of collaborative consumption category and platform}

To comprehend the differences between renting and lending, two platforms of collaborative consumption were considered for the research: (1) Airbnb and (2) Couchsurfing, both of which reside in the apartment-sharing ecosystem (Botsman \& Rogers, 2010) as peer-to-peer accommodation platforms. While the former offers a monetary-based application and online website that coordinates individuals looking to rent a room or apartment for a short-term accommodation (Benoit et al., 2017), the latter as a noncommodified form provides an online platform that intends to gather people seeking a free living space with other people who share an underutilized place in their residence (Hellwig et al., 2014). The authors consider peer-to-peer accommodation sharing platforms to be compatible with the intent of the study, as consumers encounter authentic and customized experiences during their travels owing to interactions among guests, hosts and the local community (Paulauskaite et al., 2017).

\section{Data collection methods}

As this work is of an exploratory nature, in Study 1 and 2, face-to-face and semi-structured interviews were conducted in Turkey with Turkish consumers who have previous Airbnb and Couchsurfing travel experiences. Marshall (1996) claims that in qualitative studies, understanding complicated human-based issues is more critical than the generalizability of the results. In this context, respondents were selected via judgmental sampling in order to discover information-rich cases and respondent variety (Emmel, 2013). In both Study 1 and Study 2, respondents were selected with a non-probability technique of judgmental sampling which includes the choice of participants: (a) who have at least one Airbnb or Couchsurfing experience; (b) who are in the most suitable position to give the information required; (c) whose experiences distinguish in terms of the number of experiences they had; and (d) who differ in terms of age, 
gender, and income. In this sense, judgmental sampling data provides the assurance that respondents will be expected to provide rich knowledge to the researcher by the virtue of having gone through different number of experiences. The sample size was determined with respect to the reach of the saturation point about verbatim gathered from the interviews (Strauss \& Corbin, 1998). In this sense, data collection was completed when the researchers reached the saturation point, which clarifies a status when a few distinct data were uncovered from each new interview. All interviews were recorded and transcribed for content analysis.

In Study 1, 11 semi-structured interviews were conducted as an initial study. The interview procedure involved three sections. At the beginning of the interview, respondents were asked to consider their collaborative consumption journeys for 20 minutes and write the entire story on paper by the help of short statements or bullet points, considering several points to remind their customer journey: (i) general viewpoints throughout their accommodation experience with regard to different phases of the journey (i.e., pre-accommodation, during/post accommodation); (ii) writing down all important points that come to their mind in the accommodation experience; and (iii) remind all satisfactory and unsatisfactory experiences they had in both pre-accommodation, and during/post-accommodation phases. In the second section, respondents were asked to describe their entire collaborative consumption journeys by concentrating on each experience separately and on each phase (prepurchase/purchase/post-purchase) one by one. The in-depth interviews lasted between 75 and 90 minutes.

In Study 2, 19 respondents took part in semi-structured interviews. Each interview lasted from 30-60 minutes depending on number of experiences. In total, 67 distinct collaborative consumption experiences (30 Airbnb and 37 Couchsurfing experiences) were derived from 19 in-depth interviews (see Table 1). According to insights gathered from the interview process of Study 1, it became clear that considering the purchasing process in two stages (pre-accommodation and during/post-accommodation) was a norm for respondents. In this framework, in Study 2, respondents were asked to describe their sensory, affective, cognitive, behavioural and relational experiences based on pre-accommodation and during/postaccommodation periods. Interview questions were prepared in light of the related literature concerning customer experience (Schmitt, 1999; Triantafillidou \& Siomkos, 2014). 
Table 1. Respondents in Study 2

\begin{tabular}{lllclllc}
\hline & \multicolumn{3}{c}{ AIRBNB } & \multicolumn{3}{c}{ COUCHSURFING } \\
\hline Gender & Age & $\begin{array}{c}\text { Number of } \\
\text { Experiences }\end{array}$ & & Gender & Age & $\begin{array}{c}\text { Number of } \\
\text { Experiences }\end{array}$ \\
\hline AR1 & Male & 33 & 2 & CR1 & Male & 28 & 3 \\
\hline AR2 & Female & 21 & 8 & CR2 & Female & 34 & 1 \\
\hline AR3 & Female & 48 & 6 & CR3 & Female & 37 & 5 \\
\hline AR4 & Male & 22 & 3 & CR4 & Female & 26 & 1 \\
\hline AR5 & Female & 27 & 2 & CR5 & Female & 23 & 4 \\
\hline AR6 & Female & 25 & 1 & CR6 & Male & 26 & 20 \\
\hline AR7 & Male & 24 & 2 & CR7 & Female & 29 & 2 \\
\hline AR8 & Female & 23 & 1 & CR8 & Female & 23 & 1 \\
\hline AR9 & Female & 23 & 2 & & & & \\
\hline AR10 & Male & 36 & 2 & & & & \\
\hline AR11 & Female & 33 & 1 & & & & \\
\hline Notes: AR: Airbnb Respondent; CR: Couchsurfing Respondent &
\end{tabular}

At the end of the interviews, respondents were also asked to identify the most important touchpoints they had encountered in their journeys via a questionnaire, with the understanding that each touchpoint would not have equal priority for customers. In the questionnaire, participants were asked to respond to questions designed to prioritize the distinct dimensions of experience according to their relative importance via the Analytical Hierarchy Procedure. In the last section of questionnaire, respondents were asked to address questions related to how frequently they use Airbnb/Couchsurfing, their familiarity with Couchsurfing/Airbnb and their demographic backgrounds.

\section{Data analysis methods}

The data of the first and second study were coded and analysed via qualitative content analysis as described in the literature (Kassarjian, 1977). In this respect, themes and categories were selected as units of measurement, and coded verbatims were classified under themes, categories, and sub-categories according to coding framework. Themes and categories were identified with predominantly a concept-driven way and directed content analysis, which uses predetermined themes/categories dictated by a theory or prior research findings, was applied. In Study 1, touchpoints were classified according to the framework offered by Lemon and Verhoef (2016). In Study 2, themes, categories ad sub-categories were identified as described in the literature (Brakus et al., 2009; Richins, 1997; Schmitt, 1999; Triantafillidou \& Siomkos, 2014). Additionally, as analysis of 
the data progressed, new categories and sub-categories also emerged from verbatims with a data-driven way. Two authors of this study who have extensive knowledge about the study objectives and coding protocol conducted the coding and categorizing process independently from each other. After the completion of coding process, two authors met in order to discuss and solve any discrepancies together. In this sense, the inter-coder reliability was $92 \%$ for Study 1 and $87 \%$ for Study 2, both of which are above the standard satisfactory level of $85 \%$ agreement (Kassarjian, 1977).

To analyse the data gathered from the questionnaire in Study 2, the Analytical Hierarchy Process (AHP) was used for understanding the relative importance of each experience dimension for respondents. The AHP is a multiple criteria decision-making tool which was developed by Saaty (1980). It works through a pair-wise comparison technique, and the concluding weight is based on comparing the significance of one choice alternative to another. Recently, the AHP has been used in marketing and other fields that prioritize factors influencing consumers' decisions when selecting wealth management services (e.g., Yu \& Ting, 2011); targets, origins and root causes of boycotting behaviour (e.g., Hendarto et al., 2018); customer engagement parameters (e.g., Kujur \& Singh, 2018); and applications involving trade-off models (Davies, 2001). The AHP method used in this study involves three steps. First, the input data related to each dimension of experience is generated by pair-wise comparisons based on a five-point weighting scale. In the second step, the degree of inconsistency is measured by an inconsistency index before the weights are computed and consistent results appear (Consistency Index $(\mathrm{CI}) \leq 0.1$ is acceptable). Finally, the weight of each experience type is computed using the eigenvalue method. These experience comparisons were aimed at prioritizing categories of experiences according to their relative importance rather than judging their absolute importance.

\section{RESULTS}

\section{Results of Study 1}

Study 1 explored all possible touchpoints in multiple stages of the collaborative consumption journey. Customer journey was classified under two purchasing stages: pre-accommodation and during/postaccommodation. Empirical evidence was categorized into four distinct customer experience touchpoint categories based upon the framework offered by Lemon and Verhoef (2016): (a) brand-owned touchpoints; (b) 
customer-owned touchpoints; (c) partner-owned touchpoints; and (d) social/external touchpoints (Figure 1). Although the touchpoints encountered by Airbnb and Couchsurfing consumers were the same, the more frequently- mentioned touchpoints based on experience dimensions and purchase stages differed.

\section{Brand-owned touchpoints}

Regarding brand-owned touchpoints, respondents noted their interactions with points falling under the firm's control in the pre-accommodation stage as "Website", "Mobile Application", "E-Mail", "Published Material of Company", "TV/Radio/Podcasts", "Community Meetings" and "Help Centre", while their interactive touchpoints in the during/after stages of their customer experience consisted of "Website", "Mobile "Application", "E-mail" and "Help Centre". A great deal of research, including recent studies, has emphasized the important role websites and e-mail play in the customer experience, as they often represent the first point of interaction with the company and trigger customers to engage further by extending the conversation with reminders and newsletters (Straker et al., 2015).

\section{Partner-owned touchpoints}

Respondents' highest acknowledgment of partner-owned touchpoints (those designed and controlled with the help of a firm and its partners) in the pre-accommodation period included "Search Engines", "Online Maps", "Website of Other Service Providers", "Affiliated Websites", "Print/Online Media", "TV/Radio Channels", "Profile Pages of Host", "Mobile Communication Accounts of Host" and "Website/Mobile Application System of Financial Intermediaries". In the during/post-accommodation period, respondents most often acknowledged "House of Host", "Host", "Mobile Communication Accounts of Host", "Instructions Prepared by Host" and "Treats Given by Host". As a wealth of studies reveal that the main factor driving individuals to be a part of a sharing economy is social interaction (Tussyadiah, 2015), instructions and treats given by the host come to prominence among key touchpoints in the collaborative consumption journey. As one respondent mentioned:

"When we enter the room, we recognized that the host left some treats like snacks for breakfast and instructions related to the transportation for us. It created positive feelings" (AR1). 


\section{Customer-owned touchpoints}

In terms of customer-owned touchpoints, respondents' most frequentlyreferenced touchpoints including "Profile Pages of Guest", "E-mail Account" "Social Media and Mobile Communication Accounts of Guest" in the pre-accommodation stage, while in during/post accommodation one there are touchpoints such as "Phone", "Mobile Communication Accounts of Guest", "Profile Page of Guest". Here we note that social media takes central stage and is regarded as an augmented product feature in the context of collaborative consumption, as customers highly emphasize social media as a valuable source of information (Yannopoulou et al., 2013). As one of the participants described:

"After finding the potential host on the website, I start to search this person from all distinct social media platforms in order to understand what kind of personality this person has before making the final decision" (CR5).
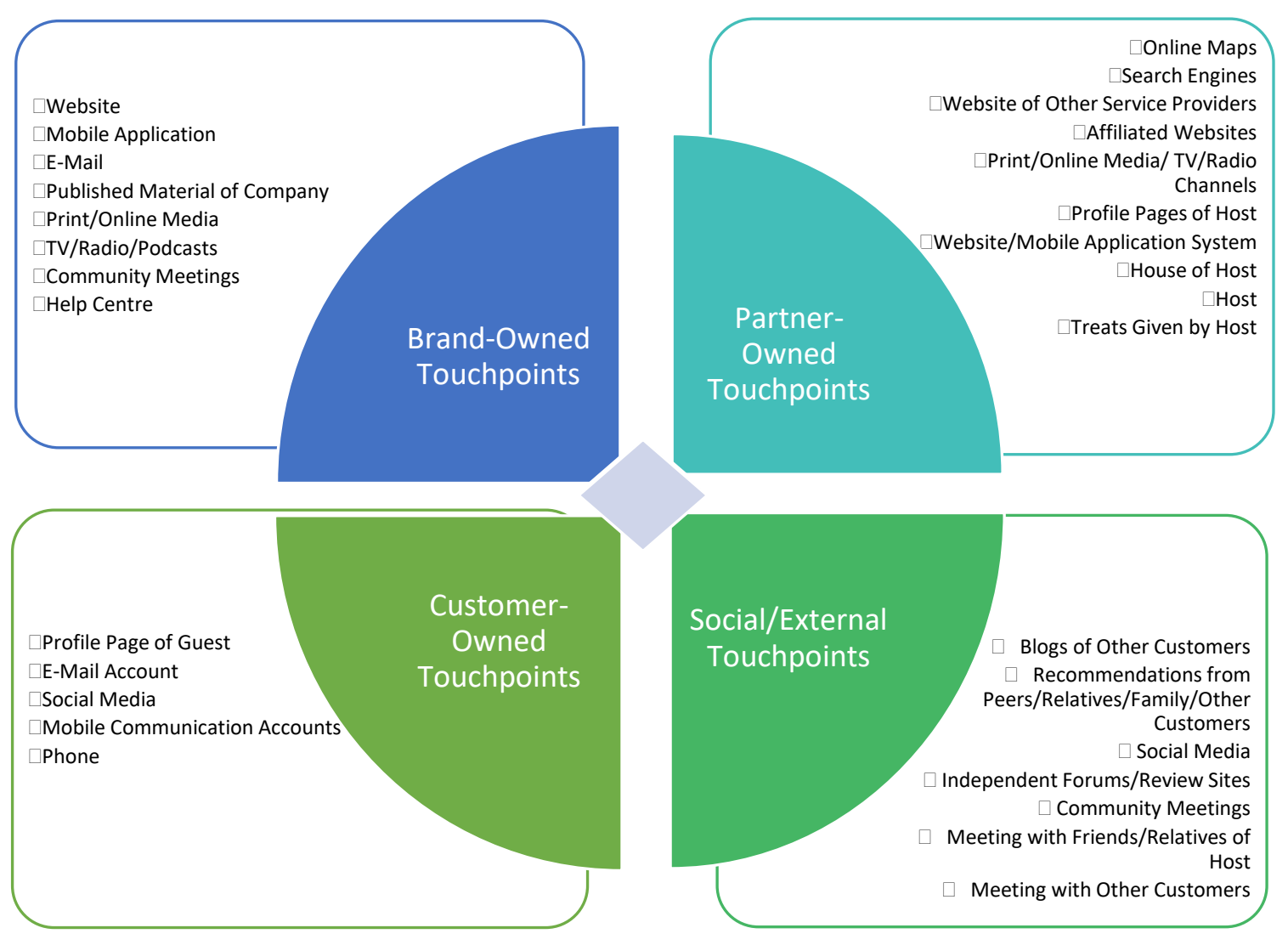

Figure 1. Classification of Touchpoints 


\section{Social/external touchpoints}

With respect to social/external touchpoints, respondents most often noted "Blogs of Other Customers", "Recommendations from Peers/Relatives/Family/Other Customers", "Social Media Accounts of Guest/Host", "Independent Forums/Review Sites" and "Community Meetings" in the pre-accommodation stage, whereas in during/post accommodation, touchpoints such as "Social Media Accounts of Guest/Host", "Meeting with Friends/Relatives of Host or Other Customers" and "Community Meetings" were prominent. In the extant literature, there is evidence suggesting that peer conversations and peer observations crucially influence the decision-making process of customers (Baxendale et al., 2015).

\section{Results of Study 2}

In the first phase of Study 2, the authors investigated the distinct experiential dimensions of the collaborative consumption journey by comparing the renting platform Airbnb with the lending platform Couchsurfing. Also, customer journey was examined with respect to the two purchasing phases involving both pre-accommodation and during/post-accommodation. The findings were aggregated under five discrete experiential dimensions building upon the scheme of Schmitt (1999): (a) sensory experience; (b) affective experience; (c) cognitive experience; (d) behavioural experience and (e) relational experience.

In general, sensory, affective and cognitive dominant experiences come into prominence for both collaborative consumption platforms in the pre-accommodation stage, whereas the collaborative consumption experience has been diversified into distinct experiences, augmenting the collaborative consumption journey with the engagement of other experiential dimensions in the during/post-accommodation stage. In the second phase, the AHP was applied to main dimensions of experience to measure the relative importance of them to each other, and results were presented in Table 2. Table 2 shows that the cognitive experience is relatively more important for Airbnb (38.4\%) in the pre-accommodation stage than it is for Couchsurfing. On the other hand, sensory experience, which has a weight of $38.4 \%$, plays a more central role for Couchsurfing in the same stage. Among the experience dimensions, affective experience is the primary concern $(27.8 \%)$, followed by behavioural experience $(19.8 \%)$ and sensory experience (19.3\%) for the Airbnb journey in the during/post- 
accommodation stage. However, in the Couchsurfing journey, relational experience $(29.4 \%)$ and behavioural experience $(22.7 \%)$ are considered much more important than other experience dimensions.

Table 2. Priority weights of experience dimensions in collaborative consumption journey

\begin{tabular}{|c|c|c|c|c|c|c|c|c|c|c|}
\hline & \multicolumn{4}{|c|}{ Pre-Accommodation } & \multicolumn{6}{|c|}{ During/Post-Accommodation } \\
\hline & U & 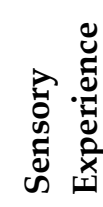 & 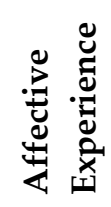 & 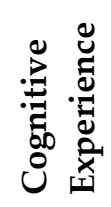 & U & 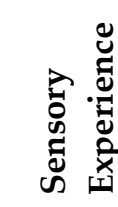 & 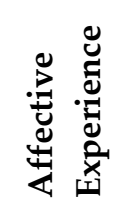 & : & 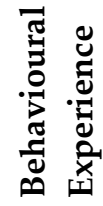 & 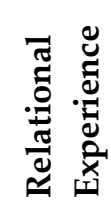 \\
\hline Airbnb & 0.084 & 0.307 & 0.309 & 0.384 & 0.090 & 0.193 & 0.278 & 0.169 & 0.198 & 0.161 \\
\hline Couchsurfing & 0.085 & 0.384 & 0.297 & 0.319 & 0.095 & 0.074 & 0.209 & 0.197 & 0.227 & 0.294 \\
\hline
\end{tabular}

\section{Sensory experience}

The first experiential dimension is sensory experience and five types of sensory experiences appear throughout the interviews: sight, sound, taste, touch and smell (see Table 3). With regard to the pre-accommodation stage, the most frequently-indicated experiential notions for both platforms are related to the sense of sight, which is the most powerful for discovering differences in the environment, and the most common in perceiving goods and services (Hultén, 2011). Frequently-inferred key sight appeals, that influence the pre-accommodation stage for Airbnb consumers involve "Photos of exteriors and interiors", "Location", "The features of accommodation" and "Photos of host", whereas for Couchsurfers they include "Photos of host", "Features of Website/mobile application" and "Photos of exteriors and interiors". It should be noted that "Photos of Exteriors and Interiors" are more important for Airbnb consumers, while "Photos of Host" are more notable for Couchsurfers. In fact, this finding can be explained by the term "visual-based trust" in the pertinent literature (e.g., Deng \& Ravichandran, 2017). Ert et al. (2016) have indicated the substantial role of a host's website photos in terms of enhancing trustbuilding and reducing uncertainty, both of which increase interactions and foment positive attitudes for customers. In this sense, typical statements made by the respondents are as follows:

"When I check the photos of the host, I have to have an impression that she/he is trustful." (CR6).

"The houses in photos have to be clean and neat. And, kitchen photos among others have a positive effect on me because it gives me more home feeling." (AR2). 
Table 3. Sensory Experience in Collaborative Consumption Journey (Airbnb vs. Couchsurfing)

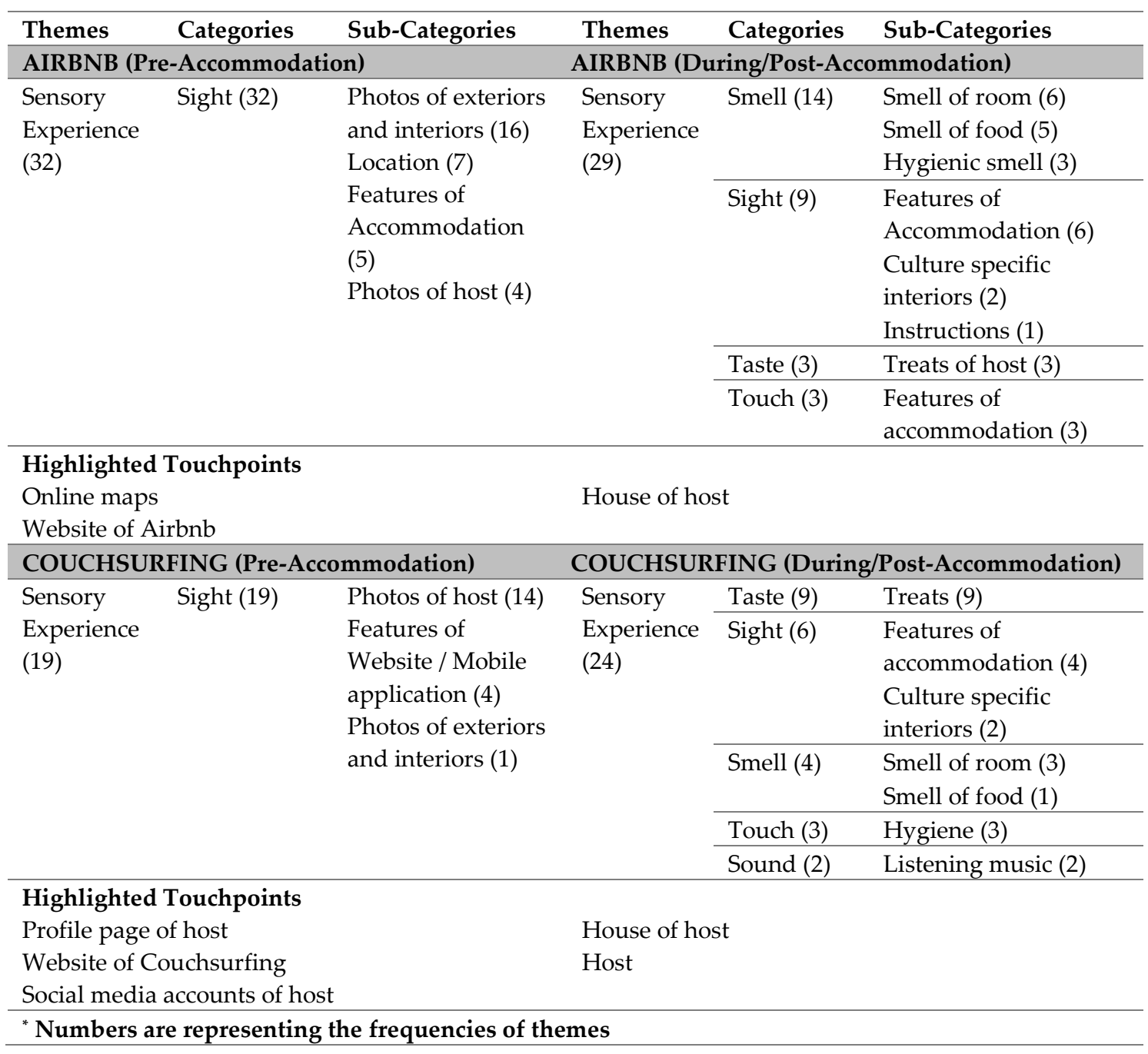

The sense module diversifies into various sensations, enriching the collaborative consumption journey with the engagement of other senses (smell, taste, touch, sound and sight) in the during/post accommodation stage. While most respondents acknowledged the sense of smell and sight for the Airbnb platform, the most frequently-indicated expressions under the sensory experience were taste and sight for the Couchsurfing platform. In this context, the sense of smell, considered a strong stimulus in the experiential marketing literature, evokes consumer emotions and plays an instrumental role in the decision-making process by influencing consumer thinking (Vinitzky \& Mazursky, 2011). Furthermore, sensory experience becomes deeper and more meaningful if combined with sensorial tastewhen consumers are exposed to different tastes and taste compositions in their experiences (Hultén, 2011). For instance: 
"Smell in the house is very important. When I entered the house, I felt the smell of cleanliness, it affected me positively." (AR10).

"She was from Thailand and cooked for me something from Thailand cuisine. Our conversation was good, and I also tasted good and different meals." (CR5).

Additionally, highlighted touchpoints mentioned by Airbnb consumers included "Online Maps" and "Website of Airbnb" in preaccommodation. Couchsurfers' responses emphasized the "Profile Page of Host" and "Social Media Accounts of Host" as different touchpoints not mentioned by Airbnb customers. For example, one interviewee stated that "I am making a search like a stalker from social media platforms to understand what kind of person is" (CR2). In the during/post-accommodation stage, "House of host" represents a key touchpoint which may create a noteworthy sensory experience; "Host" encompasses a multifaceted set of sensory experiences for Couchsurfers.

\section{Affective experience}

Affective experiences, which constitute a large spectrum, emerged from the interviews and were divided into two main categories: positive emotions and negative emotions, each involving sub-emotions based on the framework offered by Richins (1997) in the field of consumption experience (see Table 4). Respondents stated that their affective experiences carried feelings related to flow and escapism; their statements were consistent with Triantafillidou and Siomkos's (2014) study. In the pre-accommodation stage, a significant number of respondents provided evidence of "Negative emotions" in the journey of Airbnb in the framework of "Worry" and "Fear". On the other hand, respondents expressed positive feelings (i.e., excitement, peacefulness, optimism and surprise) relatively more frequently for the Couchsurfing platform during the pre-accommodation stage. This discrepancy probably stems from differences between perceived risk and fear in the two different contexts, for Olson (2013) declared that perceived fears serve as the main barrier in collaborative consumption, especially concerns about trust, quality and the value of the service provided. Besides, Airbnb, which is a monetary platform, is more subject to guests' performance expectations than Couchsurfing, a non-commodified accommodation alternative (e.g., Guttentag \& Smith, 2017). For example, regarding negative and positive emotions, the following responses were noted: 
"There were many questions in my mind. That's why, I had worry and excitement. Would we take the key at the right time, would the house be clean, would we feel ourselves relax when we slept, how is the district, is it secure or not?" (AR11).

"Before going there, my emotions were positive. I had scrutinized her profile and I had a feeling that she was a good person" (CR2).

Table 4. Affective Experience in Collaborative Consumption Journey (Airbnb vs. Couchsurfing)

\begin{tabular}{|c|c|c|c|c|c|}
\hline Themes & Categories & Sub-Categories & Themes & Categories & Sub-Categories \\
\hline \multicolumn{3}{|c|}{ AIRBNB (Pre-Accommodation) } & \multicolumn{3}{|c|}{ AIRBNB (During/Post-Accommodation) } \\
\hline \multirow{11}{*}{$\begin{array}{l}\text { Affective } \\
\text { Experience } \\
(32)\end{array}$} & Negative & Worry (16) & Affective & Positive & Joy (15) \\
\hline & Emotions & Fear (7) & Experience & emotions & Peacefulness (11) \\
\hline & $(23)$ & & $(62)$ & $(32)$ & Love (3) \\
\hline & \multirow{8}{*}{$\begin{array}{l}\text { Positive } \\
\text { Emotions (9) }\end{array}$} & \multirow{8}{*}{$\begin{array}{l}\text { Excitement (5) } \\
\text { Joy (3) } \\
\text { Peacefulness (1) }\end{array}$} & & & Excitement (2) \\
\hline & & & & & Surprise (1) \\
\hline & & & & Negative & Worry (7) \\
\hline & & & & emotions & Anger (4) \\
\hline & & & & $(12)$ & Envy (1) \\
\hline & & & & \multicolumn{2}{|l|}{$\begin{array}{l}\text { Feeling in } \\
\text { flow (6) }\end{array}$} \\
\hline & & & & \multicolumn{2}{|l|}{$\begin{array}{l}\text { Feeling in } \\
\text { escape (6) }\end{array}$} \\
\hline & & & & \multicolumn{2}{|c|}{$\begin{array}{l}\text { Not feeling } \\
\text { flow or escape (6) }\end{array}$} \\
\hline
\end{tabular}

\section{Highlighted Touchpoints}

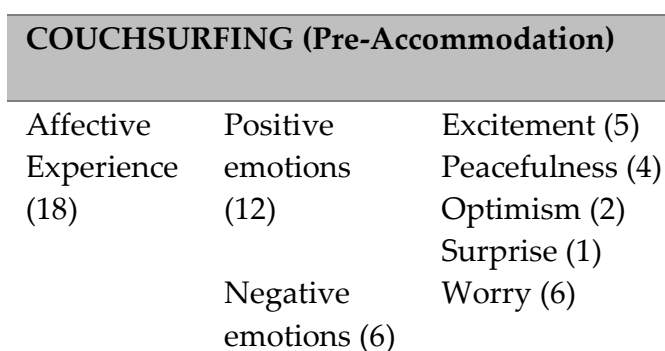

House of Host

\section{COUCHSURFING (During/Post-}

\section{Accommodation)}

Affective Positive Joy (14)

Experience emotions Peacefulness (3)

(46)

Love (2)

Surprise (2)

Contentment (1)

Excitement (1)

$\begin{array}{ll}\text { Negative } & \text { Discontent (4) } \\ \text { emotions } & \text { Anger (2) }\end{array}$

(8) Sadness (2)

Feeling in

escape (6)

Feeling in

flow (5)

Not feeling

flow or escape (4)

\section{Highlighted Touchpoints}

Host

Meeting with Friends/Relatives of Host

* Numbers are representing the frequencies of themes 
Findings related to the feel module demonstrated the same affective stimuli: "Positive emotions" consisting of "Joy", "Peacefulness", "Excitement", "Love" and "Surprise" for both platforms in the during/postaccommodation stage. Since consumption itself embodies hedonic motivations related to the need for enjoyment, fun and amusement (Holbrook \& Hirschman, 1982), several scholars have suggested that collaborative consumption activities present enjoyable experiences to customers through hedonic benefits such as having fun, entertainment and amusement (Yang \& Ahn, 2016). Furthermore, while the interactions between "House of host" and Airbnb users trigger feelings, a host's contact with Couchsurfing consumers stood as the determinant touchpoint for affective experience. Some respondents expressed the situation as follows:

"I felt happy. We were like at our own home and neighbourhood. We lived there like locals" (AR1).

"During the trip, there was happiness, fun, joy and friendship" (CR2).

Although several respondents associated flow and escape with traveling itself, some indicated that they felt themselves in flow or escape with Airbnb and Couchsurfing even during the post-accommodation period. This is supported by following statement:

"It was a bit of a getaway from the borders in society" (CR7).

\section{Cognitive experience}

The module of think implies that experiences aid customers to be both creative and analytical (Schmitt, 1999). Within the theme of cognitive experience, convergent/analytical thinking and divergent/imaginary thinking were identified as categories throughout several interviews; these identifications were consistent with the work of Brakus et al. (2009), who posited that cognitive experience consists of convergent/analytical thinking (focused on deriving the single best or correct answer) and divergent/imaginative thinking (which produces unconventional answers from existing information) (Cropley, 2006). In this sense, consumers, both in Airbnb and Couchsurfing, believe that convergent thinking is critical during the period of pre-accommodation, with emphases on "Problemsolving", "Searching", "Planning" and "Comparing" (see Table 5). This is also evident in the extant literature, as pre-accommodation requires customers to engage in activities such as information searches, evaluation of alternatives and decision-making, all of which comprise a fundamental 
basis for the customer experience within the context of travel (Xiang et al., 2015). For example:

"Our searching skills have improved greatly due to the process of finding the right house" (AR8).

"Before the trip, I'm doing some search about what I can talk to the guy. I'm looking at profile of him and I'm investigating what he likes like preparing a short assignment" (CR6).

Table 5. Cognitive Experience in Collaborative Consumption Journey (Airbnb vs. Couchsurfing)

\begin{tabular}{|c|c|c|c|c|c|}
\hline Themes & Categories & Sub-Categories & Themes & Categories & Sub-Categories \\
\hline \multicolumn{3}{|c|}{ AIRBNB (Pre-Accommodation) } & \multicolumn{3}{|c|}{ AIRBNB (During/Post-Accommodation) } \\
\hline \multirow[t]{2}{*}{$\begin{array}{l}\text { Cognitive } \\
\text { Experience } \\
(19)\end{array}$} & $\begin{array}{l}\text { Convergent / } \\
\text { analytical } \\
\text { thinking (18) }\end{array}$ & $\begin{array}{l}\text { Problem-solving } \\
(11) \\
\text { Searching (4) } \\
\text { Planning (2) } \\
\text { Comparing (1) }\end{array}$ & \multirow[t]{2}{*}{$\begin{array}{l}\text { Cognitive } \\
\text { Experience } \\
(25)\end{array}$} & $\begin{array}{l}\text { Divergent / } \\
\text { imaginary } \\
\text { thinking } \\
(16)\end{array}$ & $\begin{array}{l}\text { Exploring new things } \\
\text { (Hedonic based) (9) } \\
\text { Creativity (4) } \\
\text { Shifting perspective } \\
\text { (3) }\end{array}$ \\
\hline & $\begin{array}{l}\text { Divergent / } \\
\text { imaginary } \\
\text { thinking (1) }\end{array}$ & $\begin{array}{l}\text { Shifting } \\
\text { perspective (1) }\end{array}$ & & $\begin{array}{l}\text { Convergent } \\
\text { / analytical } \\
\text { thinking (9) }\end{array}$ & $\begin{array}{l}\text { Problem-solving }(8) \\
\text { Exploring new things } \\
\text { (Hedonic based) }(1)\end{array}$ \\
\hline \multicolumn{3}{|c|}{$\begin{array}{l}\text { Website of Airbnb } \\
\text { Search engines }\end{array}$} & \multirow{2}{*}{\multicolumn{3}{|c|}{$\begin{array}{l}\text { Notes or instructions prepared by } \mathrm{l} \\
\text { Host } \\
\text { COUCHSURFING (During/Post- } \\
\text { Accommodation) }\end{array}$}} \\
\hline COUCHSU & FING (Pre-Acc & mmodation) & & & \\
\hline \multirow[t]{3}{*}{$\begin{array}{l}\text { Cognitive } \\
\text { Experience } \\
(15)\end{array}$} & $\begin{array}{l}\text { Convergent / } \\
\text { analytical } \\
\text { thinking (14) }\end{array}$ & $\begin{array}{l}\text { Searching (8) } \\
\text { Problem-solving } \\
(4) \\
\text { Planning (2) } \\
\end{array}$ & \multirow[t]{3}{*}{$\begin{array}{l}\text { Cognitive } \\
\text { Experience } \\
(24)\end{array}$} & \multirow[t]{2}{*}{$\begin{array}{l}\text { Divergent / } \\
\text { imaginary } \\
\text { thinking } \\
(21)\end{array}$} & $\begin{array}{l}\text { Shifting perspective } \\
(9) \\
\text { Exploring new } \\
\text { cultures (5) }\end{array}$ \\
\hline & & & & & $\begin{array}{l}\text { Exploring new things } \\
\text { (Hedonic based) (4) } \\
\text { Seeing new } \\
\text { possibilities (3) }\end{array}$ \\
\hline & $\begin{array}{l}\text { Divergent / } \\
\text { imaginary } \\
\text { thinking (1) }\end{array}$ & $\begin{array}{l}\text { Exploring new } \\
\text { things (Hedonic } \\
\text { based) (1) }\end{array}$ & & $\begin{array}{l}\text { Convergent } \\
\text { / analytical } \\
\text { thinking (3) }\end{array}$ & $\begin{array}{l}\text { Exploring new things } \\
\text { (Utilitarian based) (3) }\end{array}$ \\
\hline
\end{tabular}

\section{Highlighted Touchpoints}

Search engines

Host

Profile page of host

Meeting with friends/relatives of host

Website of Couchsurfing

* Numbers are representing the frequencies of themes

In the during/post-accommodation stage, however, divergent thinking appeared as the most frequently indicated cognition point under the scheme of the think module, which implies that imaginary thinking triggers customer engagement in various cognitions. For instance, while 
think perception stimulations were often mentioned as "Exploring new things (Hedonic-based)" and "Creativity" in Airbnb, these involved "Shifting perspective" and "Exploring new cultures" for Couchsurfers. In fact, this distinction derives from the essence of the two platforms owing to their monetary and non-commodified nature. While the primary sharing resource for Couchsurfing is human interaction (i.e., friendship and social experience) and the secondary asset is house (i.e., bed, sofa and financial gains), the opposite is true for Airbnb (Jung et al., 2016), which directs customers toward local and multi-cultural interactions that may shift their perspectives (Yannopoulou et al., 2013). The following quote illustrates "Divergent / imaginary thinking" category for Airbnb and Couchsurfing.

"Once, I was staying in the apartment of a homosexual person in Amsterdam. It was like a culture shock for me. But that changed my perspective on life. I removed my prejudices." (CR6).

As part of cognitive experience, "Search engines" are becoming important touchpoints for respondents in the pre-accommodation stage. In the during/post-accommodation stage, "Notes or instructions prepared by host" helps participants solve problems related to finding good places to eat, shop and see. Additionally, interactions with "Host" and "Friends/relatives of host" provide respondents an opportunity to explore new cultures and things, see new possibilities and change perspectives.

\section{Behavioural experience}

For both platforms, the act module emerges as a dominant theme when consumers begin to interact with the accommodation place and hosts at the during/post-accommodation stage (see Table 6). With regard to Airbnb, the majority of respondents identified their behavioural experiences as: "Guiding", "Treating" and "Accommodation", as Guttentag (2015) highlighted; for example, the importance of staying in a home-like atmosphere and getting tips from local people, which contribute to the authentic local experience for Airbnb customers. In this context, respondents mentioned "Instructions prepared by host", "Meeting with other customers" and "House of host" as important touchpoints for Airbnb. On other hand, respondents expressed their bodily experiences in Couchsurfing as "Traveling around together", "Eating together" and "Guiding", which are in line with the study offered by Chen (2012), a work that emphasized the social appeal motivation of Couchsurfing-namely, the cross-cultural interactions that occur between host and guest towards the development of enduring and meaningful social relationships. 
Moreover, "Host" and "Meeting with friends/relatives of host" are critical touchpoints which shape the behavioural experience in Couchsurfing. Regarding behavioural experience, respondents stated the following:

"Just we make a short conversation and he gave us some tips about the touristic places and transportation. We did not do any activity together" (AR2).

"In Spain we went to a local party together at night" (CR3).

Table 6. Behavioural Experience in Collaborative Consumption Journey (Airbnb vs. Couchsurfing)

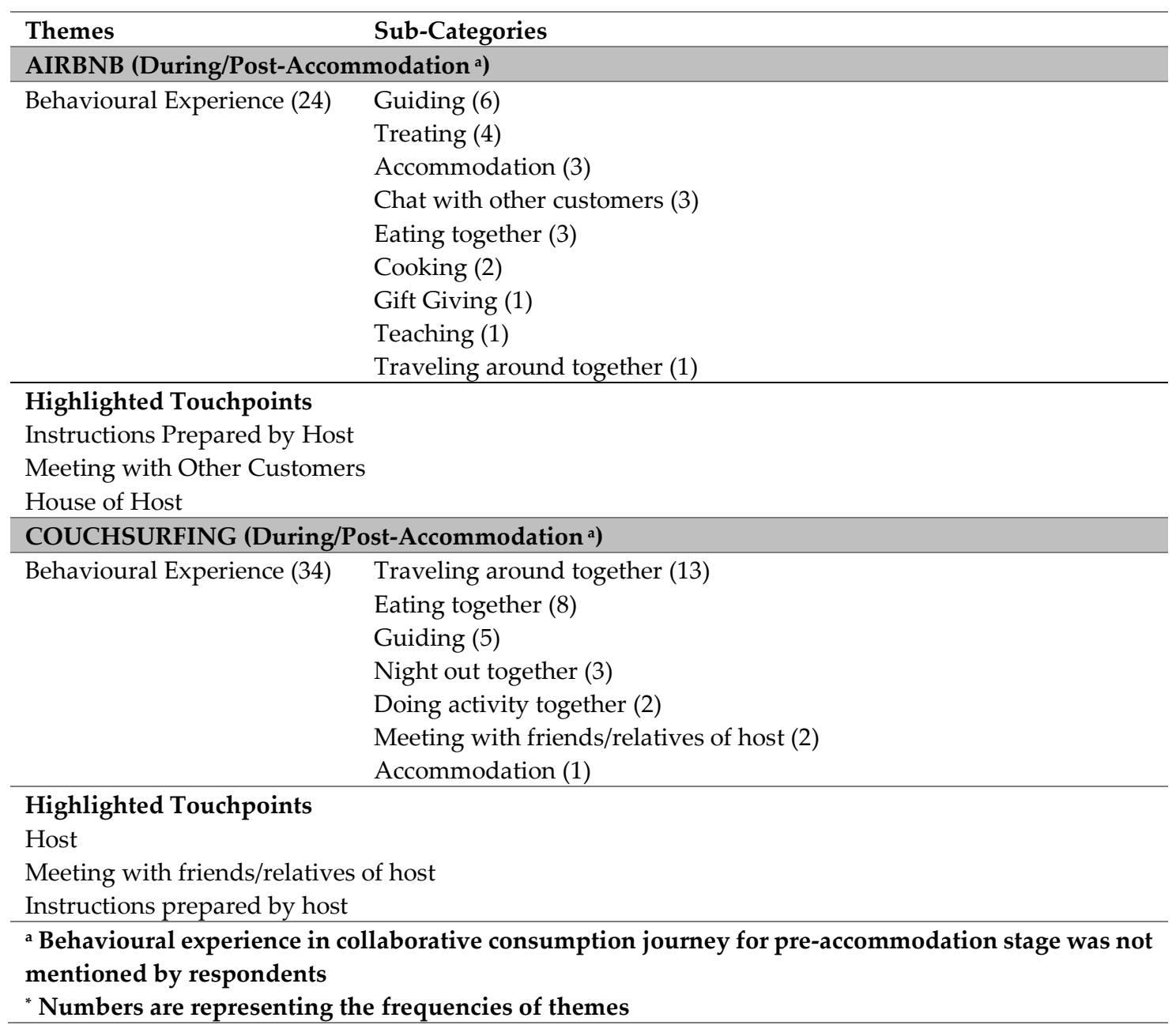

\section{Relational experience}

In Airbnb and Couchsurfing journeys, the relational experience occurs only at the during/post-accommodation stage (see Table 7). However, the relational module diversifies into several relations, enhancing the collaborative consumption journey with the involvement of other relational interactions. The most frequently-encountered statements pertaining to 
Airbnb resulted in various categories such as "Positive interaction with host", "Being part of community", "Social experience", "Interaction with friends/relatives of host" and "Interaction with other customers". These relationships are mostly positive and occur at simple involvement levels for Airbnb. The present finding supports Möhlmann's (2015) study, which concluded that no causal relationship exists between community belonging and satisfaction for Airbnb case. On the other hand, for Couchsurfers, the most frequently-mentioned relational experiences were aggregated under two categories: "Social experience" and "Being part of a community". In line with this finding, Hellwig et al. (2014) indicated that jointly-produced and consumed experiences exist at the heart of sharing in Couchsurfing. The reciprocal nature of the Couchsurfing experience depends on the exchange of ideas and thus accounts for sharing as a key point, which implies that feelings of gratitude evoke in consumers a moral obligation, pushing them to develop more intense social relationships and intimate interactions with hosts and their friends and relatives (Chen, 2012).

"We're not having a friendly relationship; I'm looking at it like a business relationship (AR3).

Table 7. Relational Experience in Collaborative Consumption Journey (Airbnb vs. Couchsurfing)

\begin{tabular}{|c|c|c|}
\hline Themes & Categories & Sub-Categories \\
\hline \multicolumn{3}{|c|}{ AIRBNB (During/Post-Accommodationa) } \\
\hline \multirow[t]{8}{*}{ Relational Experience (34) } & Interaction with host (19) & Positive interaction with host (12) \\
\hline & & Effortless interaction with host (6) \\
\hline & & Negative interaction with host (1) \\
\hline & Being part of community (5) & \\
\hline & Social experience (3) & \\
\hline & $\begin{array}{l}\text { Interaction with } \\
\text { friends/relatives of host (2) }\end{array}$ & \\
\hline & No interaction (2) & \\
\hline & $\begin{array}{l}\text { Interaction with other } \\
\text { customers (3) }\end{array}$ & \\
\hline \multicolumn{3}{|l|}{ Highlighted Touchpoints } \\
\hline \multicolumn{3}{|l|}{ Host } \\
\hline \multicolumn{3}{|l|}{ Meeting with other customers } \\
\hline \multicolumn{3}{|c|}{ COUCHSURFING (During/Post-Accommodationª) } \\
\hline \multirow[t]{2}{*}{ Relational Experience (30) } & Social experience (20) & Friendship with host (20) \\
\hline & Being part of community (10) & \\
\hline \multicolumn{3}{|l|}{ Highlighted Touchpoints } \\
\hline \multicolumn{3}{|l|}{ Host } \\
\hline \multicolumn{3}{|l|}{ Social media accounts of host } \\
\hline \multicolumn{3}{|l|}{ Community meetings } \\
\hline \multicolumn{3}{|c|}{$\begin{array}{l}\text { a Relational experience in collaborative consumption journey for pre-accommodation stage was } \\
\text { not mentioned by participants } \\
{ }^{*} \text { Numbers are representing the frequencies of themes }\end{array}$} \\
\hline
\end{tabular}


Regarding the relational experience, the highlighted touchpoints are "Host" and "Meeting with other customers" for Airbnb, and "Host", "Social media accounts of host" and "Community meetings" for Couchsurfing. Particularly, "Social media accounts of host" was used to describe ongoing friendship and communication in the Couchsurfing journey. For instance, one respondent noted that "After that, we were friends. We are communicating via Instagram. I hope he will visit me in the near future" (CR8).

\section{DISCUSSION}

To elaborate the phenomenon of the collaborative consumption journey in the context of Airbnb and Couchsurfing, this study explored touchpoints and experience dimensions for both pre-accommodation and during/postaccommodation stages. This study sheds lights on key touchpoints in the collaborative consumption journey by emphasizing website and mobile application as brand-owned; search engines, online maps, house of host, profile page of host, instructions/notes and the host himself/herself as partner-owned; and social media and meeting with friends/relatives of host as social/external touchpoints, all of which require marketers' attention. The findings indicate that monetary and non-commodified collaborative consumption platforms may have similar touchpoints, but the customer journey is significantly different in terms of experience. For that reason, experiences in collaborative consumption journeys should be analysed according to the categories of collaborative consumption, and distinct strategies for different categories should be generated. With better understanding of the experience dimensions for various types of collaborative consumption such as lending, renting, bartering and donating, marketers may generate utilitarian or hedonic incentives to support collaborative consumption. Today, many people engage in collaborative consumption, yet still many are reluctant to participate (Möhlmann, 2015). To increase numbers, marketers should work to understand all dimensions of experience in the collaborative consumption journey to ease barriers against it.

Customers make great efforts to determine the best host with a combination of the right house and right location, which leads them through intensive problem-solving processes. Their cognitive experiences are relatively more important for Airbnb than for Couchsurfing in the preaccommodation stage. Potential consumers attach importance to certain touchpoints such as websites, online maps and search engines, which 
facilitates the problem-solving process. As Rosen and Purinton (2004) pointed out, websites full of descriptive text, pictures, graphics, layouts, sounds and motions influence consumers' perceptions and experiences through cognitive psychology. In addition, Pink and Mackley (2012) have indicated how the sensory aesthetics of home-like comfort affect individuals' everyday thoughts and perceptions. In this framework, it can be suggested that Airbnb should improve its website context to provide more and better photographical/video-based information concerning residences.

In the pre-accommodation stage, sensory experience is crucial for Couchsurfers owing to their desire to find the right host with whom they may experience a worthwhile stay. As such, a host's profile page and social media accounts gain importance. According to Tussyadiah (2015), "mistrust between strangers" stands as the critical deterrent to collaborative consumption in the accommodation sector, and marketers should modify touchpoints to deal with the issue of trust. Additionally, Schreiner et al. (2018) found that reduced social distance increases individuals' willingness to share. In this framework, sharing more information about the host and confirming the reliability of that information will be critically important for the Couchsurfing platform in the future. The experience offered by the platform should make guests feel close to hosts by enriching sensory information. For instance, stories shared on the host's profile page or mobile application may create a more favourable sensory experience for consumers.

Negative emotions are also worthy for Couchsurfers and do not affect the overall attitude towards journey unfavourably. However, negative emotions such as "fear and worry" under the affective experience dimension should be contemplated, especially for Airbnb. Managers of monetary-based collaborative consumption platforms should adapt their marketing strategies to generate trust-building activities to respond to fear and worry in pre-accommodation stage. Moreover, in the during/post accommodation stage, Airbnb customers also give great importance to the affective experience. Primarily, the host's residence provokes various emotions. Providing "before and after" accommodation expectations would aid consumers. Airbnb should also prevent misleading sharing about residences on its website. Different from the case of Airbnb, in the Couchsurfing journey behavioural and relational interactions experienced between host and guest make the journey invaluable. This experience also triggers divergent and imaginary thinking that may result in new perspectives, the exploration of new cultures and things, and new 
possibilities. Especially in the during/post-accommodation stage, socialexternal touchpoints make greater sense for the cognitive, behavioural and relational experiences of Couchsurfers.

Finally, the present study is dedicated to developing suggestions that are grounded upon insights from the interviews and are intended to present fruitful research avenues for further studies in the field of the collaborative consumption journey. In this sense, the results of the study form a basis for further studies which may concentrate on causal links between touchpoints and experiential dimensions in the collaborative consumption context.

\section{LIMITATIONS AND AVENUES FOR FUTURE RESEARCH}

There were several limitations to the present study; outlining them may help provide recommendations for future research. First, the results of the present study are limited to the country of Turkey, a lack which undermines the generalizability of the findings. Future research should be performed in different contexts with an aim to increase the external validity of the findings, as perceptions of collaborative consumption consumers can differ among cultures (Molz, 2012). Second, this study solely focused on access over ownership in the sense of mode of exchange; further studies should address other modes of exchange (i.e., the transfer of ownership) such as donating, swapping and purchasing used goods under the premise of collaborative consumption. Third, this study targeted Airbnb and Couchsurfing customers regardless of their length of stay or first-time usage. Future studies may chronicle the experiences of consumers more familiar with these platforms and thus may examine responses that go beyond the first-time experience. In addition, customer attitudes may also differ regarding different lengths of stay. Fourth, this study approached the demand-side (i.e., guests) in their customer journey; future studies should also investigate the supply side (i.e., hosts). In addition, another fruitful area calling for future research is cross-cultural difference in both the sharing economy and customer journey, which has not yet been addressed in the extant literature. As one aim of this study was to initiate new research areas for further quantitative studies, future researchers should concentrate on causality among the variables explored in this study. In line with this path, future studies should empirically test relationships between touchpoints and experiential dimensions, thus providing a richer understanding of the subject matter. 


\section{REFERENCES}

Anderl, E., Becker, I., Von Wangenheim, F., \& Schumann, J. H. (2016). Mapping the customer journey: Lessons learned from graph-based online attribution modeling. International Journal of Research in Marketing, 33(3), 457-474: $10.2139 /$ ssrn.2685167.

Bagdare, S., \& Jain, R. (2013). Measuring retail customer experience. International Journal of Retail \& Distribution Management, 41(10), 790-804: 10.1108/IJRDM-08-2012-0084.

Bardhi, F., \& Eckhardt, G. M. (2012). Access-based consumption: The case of car sharing. Journal of Consumer Research, 39(4), 881-898: 10.1086/666376.

Baxendale, S., Macdonald, E. K., \& Wilson, H. N. (2015). The impact of different touchpoints on brand consideration. Journal of Retailing,91(2), 235-253: 10.1016/j.jretai.2014.12.008.

Belk, R. (2014). You are what you can access: Sharing and collaborative consumption online. Journal of Business Research, 67(8), 1595-1600: 10.1016/j.jbusres.2013.10.001.

Benkler, Y. (2004). Sharing nicely: On shareable goods and the emergence of sharing as a modality of economic production. Yale Law Journal,114(2), 273-358: $10.2307 / 4135731$.

Benoit, S., Baker, T. L., Bolton, R. N., Gruber, T., \& Kandampully, J. (2017). A triadic framework for collaborative consumption (CC): Motives, activities and resources \& capabilities of actors. Journal of Business Research, 79, 219-227: 10.1016/j.jbusres.2017.05.004.

Berry, L. L., Carbone, L. P., \& Haeckel, S. H. (2002). Managing the total customer experience. MIT Sloan Management Review, 43(3), 85-89.

Bolton,R. N., Gustafsson, A., McColl-Kennedy, J.R., Sirianni, N.J., \& Tse, D.K. (2014). Small details that make big differences: A radical approach to consumption experience as a firm's differentiating strategy. Journal of Service Management, 25(2), 253-274: 10.1108/JOSM-01-2014-0034.

Bolton, R. N., McColl-Kennedy, J. R., Cheung, L., Gallan, A., Orsingher, C., Witell, L., \& Zaki, M. (2018). Customer experience challenges: Bringing together digital, physical and social realms. Journal of Service Management, 29(5), 776-808: 10.1108/JOSM-04-2018-0113.

Botsman, R., \& Rogers, R. (2010). Beyond zipcar: Collaborative consumption. Harvard Business Review, 88(10), 30: 10.3390/resources2030184.

Brakus, J. J., Schmitt, B. H., \& Zarantonello, L. (2009). Brand experience: what is it? How is it measured? Does it affect loyalty?. Journal of marketing, 73(3), 52-68: 10.1509/jmkg.73.3.52.

Carù, A., \& Cova, B. (2003). Revisiting consumption experience: A more humble but complete view of the concept. Marketing theory,3(2), 267-286: $10.1177 / 14705931030032004$.

Chen, D. J. (2012). Global concept, local practice: Taiwanese experience of CouchSurfing. Hospitality \& Society, 1(3), 279-297: 10.1386/hosp.1.3.279_1.

Cohen, B., \& Kietzmann, J. (2014). Ride on! Mobility business models for the sharing economy. Organization \& Environment, 27(3), 279-296: 10.1177/1086026614546199.

Cropley, A. (2006). In praise of convergent thinking. Creativity Research Journal, 18(3), 391404: 10.1207/s15326934crj1803_13.

Davies, M. (2001). Adaptive AHP: A review of marketing applications with extensions. European Journal of Marketing, 35(7/8), 872-894: 10.1108/EUM0000000005729. 
Davies, B., Baron, S. and Harris, K. (1999). Observable oral participation in the servuction system: toward a content and process model. Journal of Business Research, 44,47-53: 10.1016/S0148-2963(97)00177-X.

Deng, C., \& Ravichandran, T. (2017). How consumers perceive trustworthiness of providers in sharing economy: Effects of photos and comments on demand at Airbnb. In: Proceedings of Twenty-third Americas Conference on Information System, Boston, 1-5.

Dredge, D., \& Gyimóthy, S. (2015). The collaborative economy and tourism: Critical perspectives, questionable claims and silenced voices. Tourism Recreation Research, 40(3), 286-302: 10.1080/02508281.2015.1086076.

Edelman, D. C., \& Singer, M. (2015). Competing on customer journeys. Harvard Business Review, 93(11), 88-100: 10.1509/jm.15.0420.

Emmel, N. (2013). Sampling and choosing cases in qualitative research: A realist approach. India: Sage.

Ert, E., Fleischer, A., \& Magen, N. (2016). Trust and reputation in the sharing economy: The role of personal photos in Airbnb. Tourism Management, 55, 62-73: 10.2139/ssrn.2624181.

Galbreth, M. R., Ghosh, B., \& Shor, M. (2012). Social sharing of information goods: Implications for pricing and profits. Marketing Science, 31(4), 603-620: 10.1287/mksc.1120.0706.

Gentile, C., Spiller, N., \& Noci, G. (2007). How to sustain the customer experience: An overview of experience components that co-create value with the customer. European Management Journal, 25(5), 395-410: 10.1016/j.emj.2007.08.005.

Guttentag, D. (2015). Airbnb: disruptive innovation and the rise of an informal tourism accommodation sector. Current issues in Tourism, 18(12), 1192-1217: 10.1080/13683500.2013.827159.

Guttentag, D. A., \& Smith, S. L. (2017). Assessing Airbnb as a disruptive innovation relative to hotels: Substitution and comparative performance expectations. International Journal of Hospitality Management, 64, 1-10: 10.1016/j.ijhm.2017.02.003.

Halvorsrud, R., Kvale, K., \& Følstad, A. (2016). Improving service quality through customer journey analysis. Journal of service theory and practice, 26(6), 840-867: 10.1108/JSTP-05-2015-0111.

Hamari, J., Sjöklint, M., \& Ukkonen, A. (2016). The sharing economy: Why people participate in collaborative consumption. Journal of the Association for Information Science and Technology, 67(9), 2047-2059: 10.1002/asi.23552.

Hellwig, K., Morhart, F., Girardin, F., \& Hauser, M. (2015). Exploring different types of sharing: A proposed segmentation of the market for "sharing" businesses. Psychology \& Marketing, 32(9), 891-906: 10.1002/mar.20825.

Hellwig, K., Morhart, F., Kocher, B., \& Zisiadis, G. (2014). Share your life and get more of yourself. Experience sharing in Couchsurfing. NA Advances in Consumer Research, 42, 510-511.

Hendarto, K. A., Dharmmesta, B. S., Purwanto, B. M., \& Moeliono, M. M. (2018). Analyzing consumer participation in boycott movement using the analytical hierarchy process: Indonesia context. Journal of Islamic Marketing, 9(4), 698-726: 10.1108/JIMA-11-2016-0086.

Holbrook, M. B., \& Hirschman, E. C. (1982). The experiential aspects of consumption: Consumer fantasies, feelings, and fun. Journal of Consumer Research, 9(2), 132-140: $10.1086 / 208906$. 
Homburg, C., Jozić, D., \& Kuehnl, C. (2017). Customer experience management: toward implementing an evolving marketing concept. Journal of the Academy of Marketing Science, 45(3), 377-401: 10.1007/s11747-015-0460-7.

Hultén, B. (2011). Sensory marketing: the multi-sensory brand-experience concept. European Business Review, 23(3), 256-273: 10.1108/09555341111130245.

Jung, J., Yoon, S., Kim, S., Park, S., Lee, K. P., \& Lee, U. (2016). Social or financial goals?: comparative analysis of user behaviors in Couchsurfing and Airbnb. In: Proceedings of the 2016 CHI conference extended abstracts on human factors in computing systems, ACM,2857-2863.

Kaplan, A. M., \& Haenlein, M. (2010). Users of the world, unite! The challenges and opportunities of Social Media. Business Horizons, 53(1), 59-68: 10.1016/j.bushor.2009.09.003.

Kassarjian, H. H. (1977). Content analysis in consumer research. Journal of Consumer Research, 4(1), 8-18: 10.1086/208674.

Kranzbühler, A. M., Kleijnen, M. H., Morgan, R. E., \& Teerling, M. (2018). The multilevel nature of customer experience research: An integrative review and research agenda. International Journal of Management Reviews, 20(2), 433-456.

Kujur, F., \& Singh, S. (2018). Emotions as predictor for consumer engagement in YouTube advertisement. Journal of Advances in Management Research, 15(2), 184-197: 10.1108/JAMR-05-2017-0065.

Lamberton, C. P., \& Rose, R. L. (2012). When is ours better than mine? A framework for understanding and altering participation in commercial sharing systems. Journal of Marketing, 76(4), 109-125: 10.1509/jm.10.0368.

Lemon, K. N., \& Verhoef, P. C. (2016). Understanding customer experience throughout the customer journey. Journal of Marketing, 80(6), 69-96: 10.1509/jm.15.0420.

Madran, C. \& Yakın, V. (2018). Sürdürülebilirlik ve Paylaşım Ekonomisi. In C. Ay, V. Yakın, \& İ. A. Kacar (Eds.), Paylaşım Ekonomisi (pp. 61-85). Ankara: Akademisyen Kitabevi.

Malhotra, A., \& Van Alstyne, M. (2014). The dark side of the sharing economy and how to lighten it. Communications of the ACM, 57(11), 24-27: 10.1145/2668893.

Marshall, M.N. (1996). Sampling for qualitative research. Family Practice, 13(6), 522-525: 10.1093/fampra/13.6.522.

Meyer, C., \& Schwager, A. (2007). Understanding customer experience. Harvard Business Review, 85(2), 116: 10.21863/ijcr/2015.3.2.010.

Molz, J. G. (2012). CouchSurfing and network hospitality: 'It's not just about the furniture'. Hospitality $\mathcal{E}$ Society, 1(3), 215-225: 10.1386/hosp.1.3.215_2.

Möhlmann, M. (2015). Collaborative consumption: determinants of satisfaction and the likelihood of using a sharing economy option again. Journal of Consumer Behavior, 14(3), 193-207: 10.1002/cb.1512.

Nielsen (2014). Is sharing the new buying?. Newyork: Nielsen.

Novak, T. P., Hoffman, D. L., \& Yung, Y. F. (2000). Measuring the customer experience in online environments: A structural modeling approach. Marketing Science, 19(1), $22-$ 42: $10.1287 / \mathrm{mksc}$.19.1.22.15184.

Oh, O., Agrawal, M., \& Rao, H. R. (2013). Community intelligence and social media services: A rumor theoretic analysis of tweets during social crises. Mis Quarterly, 37(2), 407-426: 10.25300/MISQ/2013/37.2.05.

Olson, K. (2013). National Study Quantifies Reality of the "Sharing Economy" Movement. Retrieved 11 January, 2020, from http://www.campbell-mithun.com/678_nationalstudy-quantifiesreality-of-the-sharing-economy-movement. 
Paulauskaite, D., Powell, R., Coca-Stefaniak, J. A., \& Morrison, A. M. (2017). Living like a local: Authentic tourism experiences and the sharing economy. International Journal of Tourism Research, 19(6), 619-628: 10.1002/jtr.2134.

Pink, S., \& Mackley, K. L. (2012). Video and a sense of the invisible: Approaching domestic energy consumption through the sensory home. Sociological Research Online, 17(1), 1-19: 10.5153/sro.2583.

Price, J. A. (1975). Sharing: The integration of intimate economies. Anthropologica, 17(1), 327: $10.2307 / 25604933$.

Pwc (2016). The Sharing Economy. Consumer Intelligence Series. London: PricewaterhouseCoopers.

Richardson, L. (2015). Performing the sharing economy. Geoforum, 67, 121-129: 10.1016/j.geoforum.2015.11.004.

Richins, M. L. (1997). Measuring emotions in the consumption experience. Journal of Consumer Research, 24(2), 127-146: 10.1086/209499.

Rifkin, J. (2000). The Age of Access: How The Shift from Ownership to Access Is Transforming Modern Life. London: Penguin.

Rosen, D. E., \& Purinton, E. (2004). Website design: Viewing the web as a cognitive landscape. Journal of Business Research,57(7), 787-794: 10.1016/S01482963(02)00353-3.

Saaty, T.L. (1980). The Analytic Hierarchy Process. McGraw-Hill: New York, NY.

Schmitt, B. (1999). Experiential marketing. Journal of marketing management, 15(1-3), 53-67: $10.1362 / 026725799784870496$.

Schmitt, B., Joško Brakus, J., \& Zarantonello, L. (2015). From experiential psychology to consumer experience. Journal of Consumer Psychology,25(1), 166-171: 10.1016/j.jcps.2014.09.001.

Schreiner, N., Pick, D., \& Kenning, P. (2018). To share or not to share? Explaining willingness to share in the context of social distance. Journal of Consumer Behaviour, 17(4), 366-378: 10.1002/cb.1717

Stephen, A. T., \& Galak, J. (2012). The effects of traditional and social earned media on sales: A study of a microlending marketplace. Journal of Marketing Research, 49(5), 624-639: 10.1509/jmr.09.0401.

Straker, K., Wrigley, C., \& Rosemann, M. (2015). The role of design in the future of digital channels: Conceptual insights and future research directions. Journal of Retailing and Consumer Services, 26, 133-140: 10.1016/j.jretconser.2015.06.004.

Strauss, A., \& Corbin, J. (1998). Basics of qualitative research techniques. Thousand Oaks, CA: Sage publications.

Triantafillidou, A., \& Siomkos, G. (2014). Consumption experience outcomes: Satisfaction, nostalgia intensity, word-of-mouth communication and behavioural intentions. Journal of Consumer Marketing, 31(6/7), 526-540: 10.1108/JCM-05-2014-0982.

Tussyadiah, I. P. (2015). An exploratory study on drivers and deterrents of collaborative consumption in travel. In I. Tussyadiah \& A. Inversini (Eds.), Information and Communication Technologies in Tourism 2015 (pp. 817-830). Switzerland: Springer.

Van Doorn, J., Mende, M., Noble, S. M., Hulland, J., Ostrom, A. L., Grewal, D., \& Petersen, J. A. (2017). Domo arigato Mr. Roboto: Emergence of automated social presence in organizational frontlines and customers' service experiences. Journal of Service Research, 20(1), 43-58: 10.1177/1094670516679272.

Vargo, S. L. \& Lusch, R. F. (2004). Evolving to a new dominant logic for marketing. Journal of Marketing, 68, 1-17: 10.1509/jmkg.68.1.1.24036. 
Verhoef, P. C., Lemon, K. N., Parasuraman, A., Roggeveen, A., Tsiros, M., \& Schlesinger, L. A. (2009). Customer experience creation: Determinants, dynamics and management strategies. Journal of Retailing, 85(1), 31-41: 10.1016/j.jretai.2008.11.001.

Verhoef, P. C., Kannan, P. K., \& Inman, J. J. (2015). From multi-channel retailing to omnichannel retailing: introduction to the special issue on multi-channel retailing. Journal of Retailing, 91(2), 174-181: 10.1016/j.jretai.2015.02.005.

Vinitzky, G., \& Mazursky, D. (2011). The effects of cognitive thinking style and ambient scent on online consumer approach behavior, experience approach behavior, and search motivation. Psychology \& Marketing, 28(5), 496-519: 10.1002/mar.20398.

Voorhees, C. M., Fombelle, P. W., Gregoire, Y., Bone, S., Gustafsson, A., Sousa, R., \& Walkowiak, T. (2017). Service encounters, experiences and the customer journey: Defining the field and a call to expand our lens. Journal of Business Research, 79, 269280: 10.1016/j.jbusres.2017.04.014.

Wang, C., \& Zhang, P. (2012). The evolution of social commerce: The people, management, technology, and information dimensions. Communications of the Association for Information Systems, 31(5), 105-127

Xiang, Z., Magnini, V. P., \& Fesenmaier, D. R. (2015). Information technology and consumer behavior in travel and tourism: Insights from travel planning using the internet.Journal of Retailing and Consumer Services, 22, 244-249: 10.1016/j.jretconser.2014.08.005.

Yang, S., \& Ahn, S. (2016). Impact of motivation for participation in the sharing economy and perceived security on attitude and loyalty toward Airbnb. International Information Institute (Tokyo). Information, 19(12), 5745-5750: 10.15722/jds.15.2.201702.21.

Yannopoulou, N., Moufahim, M., \& Bian, X. (2013). User-generated brands and social media: Couchsurfing and AirBnb. Contemporary Management Research, 9(1), 85-90: 10.7903/cmr.11116.

Yu, V. F., \& Ting, H. I. (2011). Identifying key factors affecting consumers' choice of wealth management services: an AHP approach. The Service Industries Journal, 31(6), 929939: 10.1080/02642060903078750. 